\title{
Synthesis, Biological Valuation and Molecular Docking Analysis of New 5-Benzylidene Bis-Rhodanine Derivatives
}

\author{
RAJENDRAN KUMAR and SUBBAN RAVI* \\ Department of Chemistry Karpagam Academy of higher Education, Coimbatore-21, India. \\ *Corresponding author E-mail: ravisubban @ rediffmail.com
}

http://dx.doi.org/10.13005/ojc/360609

(Received: October 13, 2020; Accepted: November 17, 2020)

\begin{abstract}
The synthesis of 5-benzylidene bis-rhodanine derivatives are reported from bis-rhodanine (III) and different aromatic aldehydes (IV) via Knoevenagel condensation reactions. All the Derivatives (V) and (Va-m) were deep-rooted by NMR spectroscopic techniques and elemental analysis. The antiproliferative study of the compounds on HeLa human cervical cancer cell line, K562 leukemic cell line and MDAMB231 breast cancer cell line were performed by MTT assay. Docking studies were carried out against the protein HPV 16E2 present in the HeLa cell line. It show good docking scores. The results indicate that the bis-rhodanine derivatives could serve as potential molecules for the development of new anticancer agents.
\end{abstract}

Keywords: 5-benzylidene bis-rhodanine, Knoevenagel condensation, Cytotoxic studies, docking studies.

\section{INTRODUCTION}

Heterocyclic compounds are a major part of synthetic therapeutic chemistry. They offer a high level of structure variety and have demonstrated to be generally utilized as therapeutic agents. They are distributed widely as a natural product. Heterocyclic compounds have great potential and the most encouraging molecule for the discovery of new drugs. Ever since the introduction of Ciglitazone and Epalrestat for the treatment of diabetes, rhodanine has attracted medicinal chemists showing favourable biological properties. ${ }^{1,2,3}$ The chemical derivatization of rhodanine gives rise to molecules with a broad range of therapeutic activities like antiviral ${ }^{4,5}$, antifungal $\left.\right|^{6,7,8}$, antibacterial ${ }^{9-16}$, antitumor ${ }^{17}$, aldose reductase inhibitors ${ }^{18-20}$ and anti-inflammatory activities. Rhodanine has also been reported as inhibitors of uridine diphosphate- $\mathrm{N}$-acetyl/L-alanine ligase $^{21}$, hepatitis $C$ virus protease inhibitors ${ }^{22}$ and also inhibitors of cancer cell migration ${ }^{23-26}$. From the laboratory, it has been reported 5-benzylidene3-ethyl rhodanine and 5-isopropylidene-3-ethyl rhodanine induced cytotoxicity in a time and concentration-dependent manner with an $\mathrm{IC}_{50}$ value of $<10 \mu \mathrm{M}^{27,28}$. Recently focus has been given on the mixture of bis-heterocyclic compounds, which showed various biological activities ${ }^{29-32}$. As part of researcher's growing interest in synthesizing bis-rhodanine ${ }^{33}$. we describe herein an easy and

This is an Open Access article licensed under a Creative Commons license: Attribution 4.0 International (CC- BY). Published by Oriental Scientific Publishing Company @ 2018 
inexpensive synthetic route for the synthesis of a set bis-rhodanine to find novel and more potent anticancer agent.

\section{Experimental procedure \\ General procedure for the synthesis of Bis- rhodanine(III)}

1.2-diamino propane $(0.01 \mathrm{~mol})$ was dissolved in water and while stirring then sodium Hydroxide $(0.04 \mathrm{~mol})$ was added. The solution was cooled at $0^{\circ} \mathrm{C}$, the solution of carbon disulfide $(0.02 \mathrm{~mol})$ was mixed into it and kept for stirring for about 4 hours. Then the water solution of sodium chloroacetate $(0.02 \mathrm{~mol})$ was mixed with it and stirred for 3 hours. Subsequently, the solution of $\mathrm{HCl}$ was added and refluxed for 2-3 hours. While cooling a precipitate appeared and then it was filtered and dried to the corresponding product(III).

\section{3,3'-(propane-1,2-diyl)bis(2-thioxothiazolidin-4-} one): (III)

Red colour solid, $58 \%$, m.p. $232^{\circ} \mathrm{C},{ }^{1} \mathrm{H}-\mathrm{NMR}$ (400 MHz, $\left.\mathrm{CDCl}_{3}\right): \delta 1.5(3 \mathrm{H}, \mathrm{d}, \mathrm{J}=6.8 \mathrm{~Hz}, \mathrm{H}-1$ "), $4.5(1 \mathrm{H}, \mathrm{m}, \mathrm{H}-2 "), 4.05(2 \mathrm{H}, \mathrm{m}, \mathrm{H}-3$ ”), $4.15(2 \mathrm{H}, \mathrm{m}$, $\mathrm{H}-5), 4.20\left(2 \mathrm{H}, \mathrm{m}, \mathrm{H}-5^{\prime}\right) .{ }^{13} \mathrm{C}-\mathrm{NMR}\left(100 \mathrm{MHz}, \mathrm{CDCl}_{3}\right)$ : $\delta 203.47$ and $204.41(\mathrm{C}=\mathrm{S}), 174.62$ and 174.54 $(\mathrm{C}=\mathrm{O}), 51.02(\mathrm{~N}-\mathrm{CH}), 44.9(\mathrm{~N}-\mathrm{CH} 2) 35.58$ and 34.28 (S-CH2), $14.46\left(\mathrm{CH}_{3}\right)$.

\section{Synthesis of 5-benzylidene bis-rhodanine derivatives(V) \& (Va-m)}

The mixture of bis-rhodanine (III) $(0.002$ mol) and substituted aromatic aldehyde (IV) and (IVa-n) $(0.004 \mathrm{~mol})$ were refluxed in glacial acetic acid $(0.004 \mathrm{~mol})$ and sodium acetate $(0.004 \mathrm{~mol})$ for 4-6 hours. The resultant mixture on cooling yielded a precipitate which was filtered, washed, dried and recrystallised (ethanol) to afford the corresponding product $(\mathrm{V}) \&(\mathrm{Va}-\mathrm{m})$.

Compound V: Yellow solid, 58\%, m.p. $298^{\circ} \mathrm{C},{ }^{1} \mathrm{H}-\mathrm{NMR}\left(400 \mathrm{MHz}, \mathrm{CDCl}_{3}\right): \delta 1.64(3 \mathrm{H}, \mathrm{d}$, $\mathrm{J}=7.5 \mathrm{~Hz}, \mathrm{H}-1$ "), $4.75(1 \mathrm{H}, \mathrm{m}, \mathrm{H}-2$ "), $3.84(2 \mathrm{H}, \mathrm{m}$, $\mathrm{H}-3$ "), 7.78 and 7.84 (2H, S, H-6 and 6'), 7.98-8.21 (10H, m, H-8 to 12 and $8^{\prime}-12$ '). ${ }^{13} \mathrm{C}-\mathrm{NMR}(100 \mathrm{MHz}$, $\left.\mathrm{CDCl}_{3}\right): \delta 203.18$ and $201.80(\mathrm{C}=\mathrm{S}), 174.50$ and $174.04(\mathrm{C}=\mathrm{O}), 115.27$ and $114.66(\mathrm{~S}-\mathrm{C}), 150.13$ and 148.83 (C-6 \& 6' benzylic carbon), 125.16 to 133.7 (Aromatic carbon), $44.21(\mathrm{~N}-\mathrm{CH} 2), 50.70(\mathrm{~N}-\mathrm{CH})$, $14.77\left(\mathrm{CH}_{3}\right)$; Found: C-57.24, H-3.77, N-5.79, O-6.62, S-26.56.
Compound Va: Yellow solid, 63\%, m.p. $296^{\circ} \mathrm{C},{ }^{1} \mathrm{H}-\mathrm{NMR}\left(400 \mathrm{MHz}, \mathrm{CDCl}_{3}\right): \delta 1.62(3 \mathrm{H}, \mathrm{d}$, $\mathrm{J}=6.7 \mathrm{~Hz}, \mathrm{H}-1$ "), $4.65(1 \mathrm{H}, \mathrm{m}, \mathrm{H}-2$ "), $3.94(2 \mathrm{H}, \mathrm{m}$, $\mathrm{H}-3$ "), $3.66\left(3 \mathrm{H}, \mathrm{S}, \mathrm{OCH}_{3}\right) 7.76$ and $7.81(2 \mathrm{H}, \mathrm{S}, \mathrm{H}-6$ and $\left.6^{\prime}\right), 7.92-8.24(8 \mathrm{H}, \mathrm{d}, \mathrm{J}=7.8 \mathrm{~Hz}, \mathrm{H}-8$ to 12 and 8'-12'). ${ }^{13} \mathrm{C}-\mathrm{NMR}\left(100 \mathrm{MHz}, \mathrm{CDCl}_{3}\right.$ ): $\delta 203.18$ and $200.85(\mathrm{C}=\mathrm{S}), 174.23$ and $174.44(\mathrm{C}=\mathrm{O}), 114.28$ and 114.73 (S-C), 150.24 and 148.78 (C-6 \& 6' benzylic carbon), 125.38 to 134.6 (Aromatic carbon), 56.3 $\left(\mathrm{OCH}_{3}\right), 45.54(\mathrm{~N}-\mathrm{CH} 2), 50.10(\mathrm{~N}-\mathrm{CH}), 14.13\left(\mathrm{CH}_{3}\right)$; Found:C-55.34, H-4.08, N-5.17, O-11.78, S-23.62.

Compound Vb: Yellow solid, 66\%, m.p. $296^{\circ} \mathrm{C},{ }^{1} \mathrm{H}-\mathrm{NMR}\left(400 \mathrm{MHz}, \mathrm{CDCl}_{3}\right): \delta 1.56(3 \mathrm{H}, \mathrm{d}$, $\mathrm{J}=6.8 \mathrm{~Hz}, \mathrm{H}-1$ "), $4.81(1 \mathrm{H}, \mathrm{m}, \mathrm{H}-2$ "), $3.77(2 \mathrm{H}, \mathrm{m}$, H-3"), 7.58 and 7.67 (2H, S, H-6 and 6'), 7.91-8.29 $\left(8 \mathrm{H}, \mathrm{d}, \mathrm{J}=7.7 \mathrm{~Hz}, \mathrm{H}-8,9,11,12\right.$ and $\left.8^{\prime}, 9^{\prime}, 11^{\prime}, 12^{\prime}\right)$. ${ }^{13} \mathrm{C}-\mathrm{NMR}\left(100 \mathrm{MHz}, \mathrm{CDCl}_{3}\right): \delta 203.28$ and 201.14 $(\mathrm{C}=\mathrm{S}), 172.42$ and $172.33(\mathrm{C}=\mathrm{O}), 116.28$ and 115.77 (S-C), 151.12 and 149.64 (C-6 \& 6' benzylic carbon), 125.35 to 134.9 (Aromatic carbon), 45.14 (N-CH2), $51.77(\mathrm{~N}-\mathrm{CH}), 14.91\left(\mathrm{CH}_{3}\right)$; Found: C-50.07, $\mathrm{H}-2.93$, $\mathrm{Cl}-12.85, \mathrm{~N}-5.07, \mathrm{O}-5.82, \mathrm{~S}-23.24$.

Compound Vc: Yellow solid, 65\%, m.p. 294 ${ }^{\circ} \mathrm{C},{ }^{1} \mathrm{H}-\mathrm{NMR}\left(400 \mathrm{MHz}, \mathrm{CDCl}_{3}\right): \delta 1.62(3 \mathrm{H}, \mathrm{d}$, $\mathrm{J}=6.7 \mathrm{~Hz}, \mathrm{H}-1$ "), $4.71(1 \mathrm{H}, \mathrm{m}, \mathrm{H}-2$ "), $3.92(2 \mathrm{H}, \mathrm{m}$, $\left.\mathrm{H}-3^{\prime \prime}\right), 7.88$ and 7.97 (2H, S, H-6 and 6'), 7.92-8.35 $\left(8 \mathrm{H}, \mathrm{d}, \mathrm{J}=7.5 \mathrm{~Hz}, \mathrm{H}-8,9,11,12\right.$ and $\left.8^{\prime}, 9,11^{\prime}, 12^{\prime}\right)$. ${ }^{13} \mathrm{C}-\mathrm{NMR}\left(100 \mathrm{MHz}, \mathrm{CDCl}_{3}\right): \delta 204.38$ and 203.85 $(\mathrm{C}=\mathrm{S}), 174.02$ and $174.21(\mathrm{C}=\mathrm{O}), 115.11$ and 114.63 (S-C), 151.02 and 149.82 (C-6 \& 6' benzylic carbon), 125.36 to 134.7 (Aromatic carbon), 44.25 (N-CH2), $50.70(\mathrm{~N}-\mathrm{CH}), 15.05\left(\mathrm{CH}_{3}\right)$; Found: C-43.15, $\mathrm{H}-2.54, \mathrm{Br}-24.98, \mathrm{~N}-4.34, \mathrm{O}-5.03, \mathrm{~S}-20.05$.

Compound Vd: Yellow solid, 65\%, m.p. $290^{\circ} \mathrm{C},{ }^{1} \mathrm{H}-\mathrm{NMR}\left(400 \mathrm{MHz}, \mathrm{CDCl}_{3}\right): \delta 1.65(3 \mathrm{H}, \mathrm{d}$, $\mathrm{J}=6.8 \mathrm{~Hz}, \mathrm{H}-1$ "), $4.85(1 \mathrm{H}, \mathrm{m}, \mathrm{H}-2$ "), $3.85(2 \mathrm{H}, \mathrm{m}$, H-3"), 7.79 and 7.83 (2H, S, H-6 and 6'), 7.96-8.25 $\left(8 \mathrm{H}, \mathrm{d}, \mathrm{J}=7.5 \mathrm{~Hz}, \mathrm{H}-8,9,11,12\right.$ and $\left.8^{\prime}, 9^{\prime}, 11^{\prime}, 12^{\prime}\right)$. ${ }^{13} \mathrm{C}-\mathrm{NMR}\left(100 \mathrm{MHz}, \mathrm{CDCl}_{3}\right): \delta 203.38$ and 201.85 $(\mathrm{C}=\mathrm{S}), 174.52$ and $174.34(\mathrm{C}=\mathrm{O}), 115.18$ and 114.83 (S-C), 151.14 and 149.94 (C-6 \& 6' benzylic carbon), 125.38 to 134.7 (Aromatic carbon), 45.15 (N-CH2), $51.80(\mathrm{~N}-\mathrm{CH}), 14.85\left(\mathrm{CH}_{3}\right)$; Found: $\mathrm{C}-48.25, \mathrm{H}-2.83$, $\mathrm{N}-9.77, \mathrm{O}-16.77, \mathrm{~S}-22.42$.

Compound Ve: Yellow solid, 62\%, m.p. $291^{\circ} \mathrm{C},{ }^{1} \mathrm{H}-\mathrm{NMR}\left(400 \mathrm{MHz}, \mathrm{CDCl}_{3}\right): \delta 1.64(3 \mathrm{H}, \mathrm{d}$, $\mathrm{J}=6.7 \mathrm{~Hz}, \mathrm{H}-1$ "), $4.84(1 \mathrm{H}, \mathrm{m}, \mathrm{H}-2 "), 3.76(2 \mathrm{H}, \mathrm{m}$, 
H-3"), $2.51\left(3 \mathrm{H}, \mathrm{S}, \mathrm{CH}_{3}\right) 7.68$ and $7.79(2 \mathrm{H}, \mathrm{S}, \mathrm{H}-6$ and 6'), 7.94-8.31 (8H, d, J=7.8 Hz, H-8,9,11,12 and 8',9,11',12'). ${ }^{13} \mathrm{C}-\mathrm{NMR}\left(100 \mathrm{MHz} \mathrm{CDCl}_{3}\right): \delta$ 200.11 and $200.92(\mathrm{C}=\mathrm{S}), 172.54$ and $172.96(\mathrm{C}=\mathrm{O})$, 115.88 and 114.97 (S-C), 151.32 and 150.27 (C-6 \& 6' benzylic carbon), 125.33 to 134.60 (Aromatic carbon), $43.26(\mathrm{~N}-\mathrm{CH} 2), 50.54(\mathrm{~N}-\mathrm{CH}), 28.4$ (phenyl methyl), $14.05\left(\mathrm{CH}_{3}\right)$; Found: C-58.78, $\mathrm{H}-4.33$, N-5.48, O-6.28, S-25.12.

Compound Vf: Yellow solid, 63\%, m.p. $302^{\circ} \mathrm{C},{ }^{1} \mathrm{H}-\mathrm{NMR}\left(400 \mathrm{MHz}, \mathrm{CDCl}_{3}\right): \delta 1.46(3 \mathrm{H}, \mathrm{d}$, J=6.7 Hz, H-1"), 4.63 (1H, m, H-2"), 3.77 (2H, m, H-3"), 7.72 and 7.85 (2H, S, H-6 and 6'), 7.88-8.33 (8H, d, J=7.5 Hz, H-8,9,11,12 and 8',9',11',12'). ${ }^{13} \mathrm{C}-\mathrm{NMR}\left(100 \mathrm{MHz}, \mathrm{CDCl}_{3}\right): \delta 200.38$ and 200.76 $(\mathrm{C}=\mathrm{S}), 174.33$ and $174.01(\mathrm{C}=\mathrm{O}), 115.17$ and 114.81 (S-C), 151.11 and 149.90 (C-6 \& 6' benzylic carbon), 125.30 to 134.6 (Aromatic carbon), $44.18(\mathrm{~N}-\mathrm{CH} 2)$, $51.86(\mathrm{~N}-\mathrm{CH}), 14.81\left(\mathrm{CH}_{3}\right)$; Found: C-53.27, H-3.12,F-7.34, N-5.42, O-6.18, S-24.72.

Compound Vg: Yellow solid, 63\%, m.p. $288^{\circ} \mathrm{C},{ }^{1} \mathrm{H}-\mathrm{NMR}\left(400 \mathrm{MHz}, \mathrm{CDCl}_{3}\right): \delta 1.56(3 \mathrm{H}, \mathrm{d}$, $\mathrm{J}=6.8 \mathrm{~Hz}, \mathrm{H}-1$ "), 4.80 (1H, m, H-2"), $3.63(2 \mathrm{H}, \mathrm{m}$, H-3"), $5.44(1 \mathrm{H}, \mathrm{S}, \mathrm{OH}) 7.73$ and $7.81(2 \mathrm{H}, \mathrm{S}, \mathrm{H}-6$ and 6'), 7.95-8.26 (8H, d, J=7.8 Hz, H-8,9,11,12 and 8',9',11',12'). ${ }^{13} \mathrm{C}-\mathrm{NMR}\left(100 \mathrm{MHz}, \mathrm{CDCl}_{3}\right): \delta 203.11$ and $203.85(C=S), 170.42$ and $171.03(C=O)$, 114.98 and 114.21 (S-C), 151.03 and 150.14 (C-6 \& 6' benzylic carbon), 125.35 to 135.5 (Aromatic carbon), $44.15(\mathrm{~N}-\mathrm{CH} 2), 50.66(\mathrm{~N}-\mathrm{CH}), 14.79\left(\mathrm{CH}_{3}\right)$; Found: C-53.68, H-3.53, N-5.44,O-12.43, S-24.92.

Compound Vh: Yellow solid, 59\%, m.p. $287^{\circ} \mathrm{C},{ }^{1} \mathrm{H}-\mathrm{NMR}\left(400 \mathrm{MHz}, \mathrm{CDCl}_{3}\right): \delta 1.63(3 \mathrm{H}, \mathrm{d}$, $\mathrm{J}=6.8 \mathrm{~Hz}, \mathrm{H}-1$ "), 4.72 (1H, m, H-2"), 3.81 (2H, m, H-3"), 7.70 and 7.81 (2H, S, H-6 and 6'), 7.95-8.29 $\left(8 \mathrm{H}, \mathrm{d}, \mathrm{J}=7.6 \mathrm{~Hz}, \mathrm{H}-8\right.$ to 10,12 and $8-10$ ', 12'). ${ }^{13} \mathrm{C}-$ $\operatorname{NMR}\left(100 \mathrm{MHz}, \mathrm{CDCl}_{3}\right): \delta 203.30$ and $202.66(\mathrm{C}=\mathrm{S})$, 170.51 and $171.24(\mathrm{C}=\mathrm{O}), 115.33$ and $114.78(\mathrm{~S}-\mathrm{C})$, 151.23 and 149.99 (C-6 \& 6' benzylic carbon), 125.30 to 134.65 (Aromatic carbon), $42.11(\mathrm{~N}-\mathrm{CH} 2), 51.01$ $(\mathrm{N}-\mathrm{CH}), 14.77\left(\mathrm{CH}_{3}\right)$; Found: C-50.08, H-2.93, Cl12.85, N-5.09, O-5.80, S-23.25.

Compound Vi: Yellow solid, 64\%, m.p. $287^{\circ} \mathrm{C},{ }^{1} \mathrm{H}-\mathrm{NMR}\left(400 \mathrm{MHz}, \mathrm{CDCl}_{3}\right): \delta 1.64(3 \mathrm{H}, \mathrm{d}$, $\mathrm{J}=6.8 \mathrm{~Hz}, \mathrm{H}-1$ ”), 4.86 (1H, m, H-2"), 3.86 (2H, m, H-3"), 7.74 and 7.80 (2H, S, H-6 and 6'), 7.99-8.21 $\left(8 \mathrm{H}, \mathrm{d}, \mathrm{J}=7.7 \mathrm{~Hz}, \mathrm{H}-8\right.$ to 10,12 and $\left.8^{\prime}-10^{\prime}, 12^{\prime}\right)$.
${ }^{13} \mathrm{C}-\mathrm{NMR}\left(100 \mathrm{MHz}, \mathrm{CDCl}_{3}\right): \delta 200.38$ and 200.85 $(\mathrm{C}=\mathrm{S}), 170.52$ and $171.32(\mathrm{C}=\mathrm{O}), 116.13$ and 113.81 (S-C), 151.12 and 149.95 (C-6 \& 6' benzylic carbon), 125.36 to 134.5 (Aromatic carbon), $45.19(\mathrm{~N}-\mathrm{CH} 2)$, $51.85(\mathrm{~N}-\mathrm{CH}), 14.82\left(\mathrm{CH}_{3}\right)$; Found:C-43.12, H-2.53, $\mathrm{Br}-24.94, \mathrm{~N}-4.38, \mathrm{O}-5.02, \mathrm{~S}-20.04$.

Compound Vj: Yellow solid, 60\%, m.p. $299^{\circ} \mathrm{C},{ }^{1} \mathrm{H}-\mathrm{NMR}\left(400 \mathrm{MHz}, \mathrm{CDCl}_{3}\right): \delta 1.64(3 \mathrm{H}, \mathrm{d}$, $\mathrm{J}=6.8 \mathrm{~Hz}, \mathrm{H}-1$ "), $4.89(1 \mathrm{H}, \mathrm{m}, \mathrm{H}-2$ "), $3.86(2 \mathrm{H}, \mathrm{m}$, $\mathrm{H}-3$ '), 7.79 and 7.88 (2H, S, H-6 and 6'), 7.94-8.22 $\left(8 \mathrm{H}, \mathrm{d}, \mathrm{J}=7.6 \mathrm{~Hz}, \mathrm{H}-8\right.$ to 10,12 and $\left.8^{\prime}-10^{\prime}, 12^{\prime}\right)$. ${ }^{13} \mathrm{C}-\mathrm{NMR}\left(100 \mathrm{MHz} \mathrm{CDCl}_{3}\right): \delta 201.39$ and 202.87 $(\mathrm{C}=\mathrm{S}), 175.58$ and $175.32(\mathrm{C}=\mathrm{O}), 114.17$ and 114.82 (S-C), 150.18 and 149.97 (C-6 \& 6' benzylic carbon), 125.39 to 134.9 (Aromatic carbon), $45.18(\mathrm{~N}-\mathrm{CH} 2)$, $51.85(\mathrm{~N}-\mathrm{CH}), 14.84\left(\mathrm{CH}_{3}\right)$; Found: C-53.22, H-3.11,F-7.36, N-5.43, O-6.19, S-24.71.

Compound Vk: Yellow solid, 60\%, m.p. $289^{\circ} \mathrm{C},{ }^{1} \mathrm{H}-\mathrm{NMR}\left(400 \mathrm{MHz}, \mathrm{CDCl}_{3}\right): \delta 1.66(3 \mathrm{H}, \mathrm{d}$, J=6.8 Hz, H-1"), 4.87 (1H, m, H-2"), $3.89(2 \mathrm{H}, \mathrm{m}$, H-3"), 7.74 and 7.81 (2H, S, H-6 and 6'), 7.95-8.27 $\left(6 \mathrm{H}, \mathrm{d}, \mathrm{J}=7.5 \mathrm{~Hz}, \mathrm{H}-8\right.$ to 10 and $\left.8^{\prime}-10^{\prime}\right) .{ }^{13} \mathrm{C}-\mathrm{NMR}$ $\left(100 \mathrm{MHz}, \mathrm{CDCl}_{3}\right): \delta 202.39$ and $201.83(\mathrm{C}=\mathrm{S})$, 174.51 and $174.34(\mathrm{C}=\mathrm{O}), 115.17$ and 114.82 (S-C), 151.13 and 149.98 (C-6 \& 6' benzylic carbon), 125.39 to 134.5 (Aromatic carbon), $45.17(\mathrm{~N}-\mathrm{CH} 2)$, $51.85(\mathrm{~N}-\mathrm{CH}), 14.88\left(\mathrm{CH}_{3}\right)$; Found: C-53.24, H-3.19, F-7.35, N-5.42, O-6.18, S-24.74.

Compound VI: Yellow solid, 58\%, m.p. $295^{\circ} \mathrm{C},{ }^{1} \mathrm{H}-\mathrm{NMR}\left(400 \mathrm{MHz}, \mathrm{CDCl}_{3}\right): \delta 1.68(3 \mathrm{H}, \mathrm{d}$, $\mathrm{J}=6.8 \mathrm{~Hz}, \mathrm{H}-1$ "), $4.88(1 \mathrm{H}, \mathrm{m}, \mathrm{H}-2$ "), $3.84(2 \mathrm{H}, \mathrm{m}$, H-3"), 7.78 and 7.81 (2H, S, H-6 and 6'), 7.97-8.28 (4H, S, H-8, 12 and 8',12'). ${ }^{13} \mathrm{C}-\mathrm{NMR}(100 \mathrm{MHz}$, $\left.\mathrm{CDCl}_{3}\right): \delta 203.39$ and $201.84(\mathrm{C}=\mathrm{S}), 174.51$ and $174.35(\mathrm{C}=\mathrm{O}), 115.19$ and $114.85(\mathrm{~S}-\mathrm{C}), 151.13$ and 149.95 (C-6 \& 6' benzylic carbon), 125.39 to 134.8 (Aromatic carbon), $45.17(\mathrm{~N}-\mathrm{CH} 2), 58.8\left(\mathrm{OCH}_{3}\right)$, $51.82(\mathrm{~N}-\mathrm{CH}), 14.83\left(\mathrm{CH}_{3}\right)$; Found: C-44.53, H-2.26, $\mathrm{Cl}-22.85, \mathrm{~N}-4.53, \mathrm{O}-5.17, \mathrm{~S}-20.66$.

Compound Vm: Yellow solid, 65\%, m.p. $290^{\circ} \mathrm{C},{ }^{1} \mathrm{H}-\mathrm{NMR}\left(400 \mathrm{MHz}, \mathrm{CDCl}_{3}\right): \delta 1.61(3 \mathrm{H}, \mathrm{d}$, $\mathrm{J}=6.8 \mathrm{~Hz}, \mathrm{H}-1$ "), 4.80 (1H, m, H-2"), $3.85(2 \mathrm{H}, \mathrm{m}$, H-3"), 7.79 and 7.83 (2H, S, H-6 and 6'), 7.96-8.25 $(8 \mathrm{H}, \mathrm{d}, \mathrm{J}=7.6 \mathrm{~Hz}, \mathrm{H}-8,10,11,12$ and 8',10',11',12'). ${ }^{13} \mathrm{C}-\mathrm{NMR}\left(100 \mathrm{MHz}, \mathrm{CDCl}_{3}\right.$ ): $\delta 203.38$ and 201.85 $(\mathrm{C}=\mathrm{S}), 174.52$ and $174.34(\mathrm{C}=\mathrm{O}), 115.18$ and 114.83 (S-C), 151.14 and 149.94 (C-6 \& 6' benzylic carbon), 
125.38 to 134.7 (Aromatic carbon), 45.15 (N-CH2), $51.80(\mathrm{~N}-\mathrm{CH}), 14.85\left(\mathrm{CH}_{3}\right)$; Found: C-48.25, $\mathrm{H}-2.83$, $\mathrm{N}-9.77, \mathrm{O}-16.77, \mathrm{~S}-22.42$.

\section{Anticancer activity \\ Cell Line}

The cervical cell line HeLa, leukemic cell line K562 and the cell line MDAMB231 for breast cancer were received from NCCS-National Center for Cell Science, Pune and grown.

\section{MTT assay}

MTT assay was followed by the standard protocol according to Rajendran Kumar et al., The worth of $\mathrm{IC}_{50}$ was calculated with a nonlinear regression graph that strategized amid current inhibition of cells in one axis and concentration of logs oneother.

\section{LDH assay}

Lactate dehydrogenase release assay liberates, Lactate dehydrogenase $(\mathrm{LDH})$ is a pointer of membrane integrity and henceforth cell injury. Following treatment with compound Vf (3.12, 6.25, 12.5, 25, 50 and $100 \mu \mathrm{g} / \mathrm{mL})$ on HeLa, K562, MDAMB231 cancer cells for $48 \mathrm{~h}$ and it was conducted to measure the proclamation of $\mathrm{LDH}$ on the way to the media and measured using standard protocols (Moorthy et al., 2010). The intracellular LDH was determined by fast congelation and melting in liquid nitrogen after losing the cells. The proclamation of $\mathrm{LDH}$ was calculated at an absorption rate of $490 \mathrm{~nm}$. The releasing proportion of LDH was measured for example (media LDH activity)/(Media LDH activity) $X 100 \%$. Outcomes are exposed as a proportion of LDH release that substrates switch standards from the preserved ones.

\section{FACS analysis}

Analysis of the FACS was performed to determine compound 1 had any effect on the development of cell cycles. After $48 \mathrm{~h}$ of 50 and 100 $\mu \mathrm{g} / \mathrm{mL}$ treatments, MDAMB231 cells stained with propidium iodide and endangered to FACS. The DMSO treated cells showed a regular pattern for the cell rotation. Cells were treated with compound $\mathrm{Vf}$ absorptions of 50 and $100 \mu \mathrm{g} / \mathrm{mL}$ and incubated for further 24 hours. At room temperature, cells were gathered then centrifuged for $5 \mathrm{~min}$ at 2000rpm. The supernatant was carefully removed, preserving the cell pellet. The cell pellet washed through re-dangling in $2 \mathrm{~mL}$ of $1 \mathrm{XPBS}$. With the same conditions, the washing was repeated for another time. The supernatant abandoned, with the pellet was retained. Cells set by resuspending in $300 \mu \mathrm{L}$ of Sheath fluid. Preceded by adding $1 \mathrm{~mL}$ of chilled $70 \% \mathrm{EtOH}$ dropwise with constant gentle shaking, and adding another $1 \mathrm{~mL}$ again.

\section{Docking studies}

The mark protein nominated for the current research is HPV 16 E2 protein. The manufactured bis-rhodanine derivatives were practiced for molecular docking study.

\section{Molecular Docking}

The study of Docking under the default setting was done using Autodock with a binding pocket on the TAD. The result was analyzed using PYMOL (TM) by visualizing the protein-ligand and calculating parameters like hydrogen bonding amid protein and the ligand thus, determining scores are tabulated.

\section{RESULT AND DISCUSSION}

While doing the literature survey to the best of our knowledge, there is only one report available for the synthesis of bis-rhodanine using diamines, Carbon disulfide and dialkylacetylenedi carboxylates $^{32}$. In the present work, diamines, Carbon disulfide, and chloroacetic acid for the synthesis of bis-rhodanine are used. To found the optimal reaction conditions for the integration of bis-rhodanine, it is decided to begin with the conventional method. In this method, one mole of diamine and two moles of carbon disulfide and chloroacetic acid are used. The dithioamide is formed initially by the reaction of carbon disulfide and diamine serves as a nucleophile and reacts further with chloroacetic acid followed by cyclization yield bis-rhodanine (III). This method have been reported earlier ${ }^{33}$, but the mechanism was not explained adequately. Now the device is shown in Scheme 2.

New derivatives were synthesized by Knoevenagel condensation of bis-rhodanine(III) with different substituted aldehydes (IV) in the presence of sodium acetate and acetic acid to yield the products (V) and (Va-m). The newly synthesized 5-benzylidenebis-rhodanine derivatives were fully characterized by proton NMR, carbon NMR spectral data and elemental analysis. 
<smiles>[R]c1ccc(C=O)cc1</smiles>

III

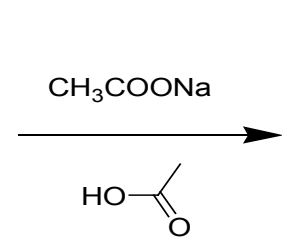

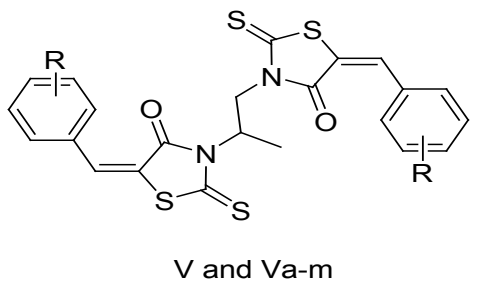

$\mathrm{V}$ and Va-m
In the ${ }^{1} \mathrm{H}-\mathrm{NMR}$ spectra of a representative compound $\mathrm{Ve}$ in the upfield region the $\mathrm{N}$-methylene protons resonated at $\delta 3.76\left(2 \mathrm{H}, \mathrm{m}, \mathrm{H}-3^{\prime \prime}\right)$, the methyl group appeared as a doublet at $\delta 1.64(3 \mathrm{H}, \mathrm{J}=6.7$ $\mathrm{Hz}$ ), and the corresponding methine proton appeared as a multiplet at $\delta 4.8(1 \mathrm{H}, \mathrm{m}, \mathrm{H}-2 ")$. The two singlets at $\delta 7.68(1 \mathrm{H}, \mathrm{s}, \mathrm{H}-6)$ and $7.79(1 \mathrm{H}, \mathrm{s}, \mathrm{H}-6)$ were attributed to the benzylic protons one on each side. The Phenyl protons appeared as a pair at $\delta 7.96(4 \mathrm{H}$, $\mathrm{d}, \mathrm{J}=7.8 \mathrm{~Hz}$ ) and $8.15(4 \mathrm{H}, \mathrm{d}, \mathrm{J}=7.8 \mathrm{~Hz})$. The $\mathrm{CH}_{3}$ group attached to the phenyl ring resonated at 2.51 $\left(3 \mathrm{H}, \mathrm{S}, \mathrm{CH}_{3}\right)$. The above data was complemented by its carbon NMR spectra. The pair of signals at $\delta 200.11$ and 200.92 and $\delta 174.87$ and 174.62 are due to thiocarbonyl $(\mathrm{C}=\mathrm{S})$ and carbonyl carbon

\begin{tabular}{|c|c|}
\hline $\begin{array}{l}\text { V; } \mathrm{H}, \\
\mathrm{Va} ; 4-\mathrm{OCH}_{3}, \\
\mathrm{Vb} ; 4-\mathrm{Cl}, \\
\mathrm{Vc} ; 4-\mathrm{Br}, \\
\text { Vd; } 4-\mathrm{NO}_{2}, \\
\text { Ve; } 4-\mathrm{CH}_{3}, \\
\text { Vf } ; 4-\mathrm{F},\end{array}$ & $\begin{array}{l}\mathrm{Vg} ; 4-\mathrm{OH} \\
\mathrm{Vh} ; 3-\mathrm{Cl} \\
\mathrm{Vi} ; 3-\mathrm{Br} \\
\mathrm{Vj} ; 3-\mathrm{F} \\
\mathrm{Vk} ; 2,3-\mathrm{Cl} \\
\mathrm{VI} ; 2,3-\mathrm{OCH}_{3} \\
\mathrm{Vm} ; 3-\mathrm{NO}_{2}\end{array}$ \\
\hline
\end{tabular}

$(C=O)$ of the rhodanine ring system respectively. The pair of signals at $\delta 115.88$ and 114.97 are due to the =C-S group of the rhodanine system. The $\mathrm{CH}_{3}$ carbon appeared at $\delta 14.05$, and the $\mathrm{CH}_{2}$ and $\mathrm{CH}$ carbons attached to the nitrogen resonated at 50.54 and 43.26. The signals at $\delta 151.32$ and 150.27 are assigned to the benzylic carbons (C-6 \& C-6'). The methyl carbon attached to the aromatic system appeared at $\delta 28.4$. The bunches of signalsbetween 125.33 to 134.60 are attributed to the phenyl carbon atoms. All the other messages of the compound (V) and (Va-m) coincided with signs of compound(Ve).

\section{Mechanism}

\section{$\underset{\mathrm{RT}, 3 \mathrm{H}, \text { Stirring }}{\stackrel{\mathrm{C} 1-\mathrm{CH}_{2} \mathrm{COONa}}{\longrightarrow}}$}

I

II
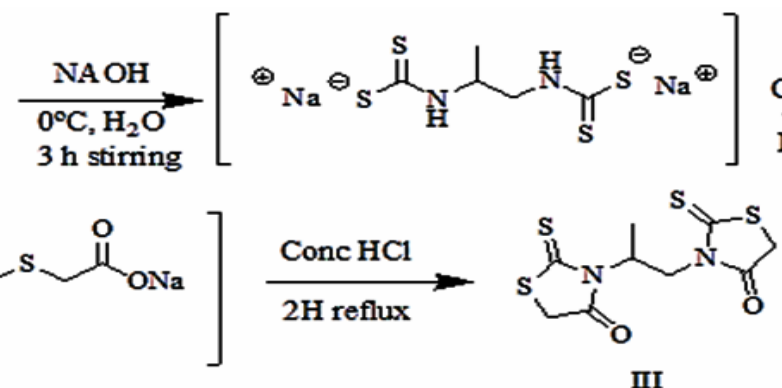

III

Scheme 1. Synthesis of bis-rhodanine (III)<smiles>CC(CN1C(=O)CSC1=S)N1C(=O)CSC1=S</smiles>

III<smiles>[R]c1ccc(C=O)c(C=O)c1</smiles>

IV andIVa-m<smiles>[R]c1cccc(/C=C2/SC(=S)N(C[C@H](C)N3C(=O)/C(=C/c4ccccc4)SC3=S)C2=O)c1</smiles>

Scheme 2. Synthesis of 5-benzylidene bis-rhodanine derivatives (V) and (Va-m) 


\section{Cytotoxic activity}

The effect of compounds $V$ and Va-m on the proliferation of HeLa, MDAMB231 and K562 cells were carried out using MTT assay. HeLa, MDAMB231, and K562 cells were added with 3.12 , $6.25,12.5,25,50$ and $100 \mu \mathrm{M}$ of compounds $V$ and Va-m and after $48 \mathrm{~h}$ the assay was performed. $\mathrm{IC}_{50}$ values were calculated and presented in the Table 1. The viability of the cells were affected at a moderate concentration in all the derivatives $\mathrm{V}$ and Va-m with HeLa, MDAMB231 and K562 cells and was more pronounced in the case of the compound $\mathrm{Vf}$ against MDAMB231 breast cancer cell lines. The compound $V$ without any substituents should be an $I_{50}$ value of 75.0, 85.4, and $72 \mu \mathrm{M}$ concentration against HeLa, MDAMB231, and K562 cells. The $\mathrm{IC}_{50}$ value of all the other compounds Va-m which has substituents in the aromatic system has varied substantially from the $I C_{50}$ value of compound $V$ against the three cell lines. This indicates that the substituents affect the proliferation activity against the three cell lines. If we divide these substituents into two groups like electron-withdrawing substituents $\left(\mathrm{NO}_{2}, \mathrm{~F}, \mathrm{Cl}\right.$ and $\left.\mathrm{Br}\right)$ and electron-pumping substituents $\left(-\mathrm{OCH}_{3}, \mathrm{OH}\right.$ and $\mathrm{CH}_{3}$ ) and consider the $\mathrm{IC}_{50}$ value concerning HeLa cell lines, the activity in compounds with electronwithdrawing groups $\mathrm{Vb}, \mathrm{Vc}$, Vd, Vf showed lower $\mathrm{IC}_{50}$ costs than the compounds with electron-donating substituents $\mathrm{Va}$, Ve and Vg. As an example, the IC50 value of compound $\mathrm{Va}$ with an electron-donating substituent $-\mathrm{OCH}_{3}$ is $81.2 \mu \mathrm{M}$.

In contrast, for the compound with electronwithdrawing substituent fluorine in $\mathrm{Vf}$, the $\mathrm{IC}_{50}$ value is $54 \mu \mathrm{M}$. The same trend is followed in MDAMB231 and K562 cells too. Further the compounds are divided into two groups depending upon the position of the substituent placed in the aromatic ring-like parasubstituted compounds Va to $V g$ and meta substituted compounds $\mathrm{Vh}, \mathrm{Vi}, \mathrm{Vj}$, and $\mathrm{Vm}$, the $\mathrm{IC}_{50}$ value of parasubstituted compounds and relatively lower than the meta substituted compounds. The $\mathrm{IC}_{50}$ value of $\mathrm{Vf}$ with a para-substituted fluorine group has an $\mathrm{IC}_{50}$ value of $54 \mu \mathrm{M}$, whereas the corresponding compound with meta substituted fluorine group showed an IC ${ }_{50}$ amount of $61 \mu \mathrm{M}$. Overall concerning all the three HeLa, MDAMB231, and K562 cell lines, the mixture Vf with a para-substituted fluorine atom performed well. It showed $\mathrm{an}_{\mathrm{IC}}$ value of $54.0,32.0$, and 58.0 against HeLa, MDAMB231, and K562 cell lines, respectively. So compound Vf was taken for further studies.
Table 1: Inhibitory effect of compounds (V) and (Va-m)oncytotoxic activity by MTT assay

\begin{tabular}{|c|c|c|c|c|c|c|}
\hline $\begin{array}{l}\text { S } \\
\text { No }\end{array}$ & Compound & $\mathrm{R}$ & $\begin{array}{c}\mathrm{IC}_{50}, \mathrm{MM} \\
\mathrm{HeLa}\end{array}$ & MDAMB231 & K562 & $\begin{array}{l}\text { Binding } \\
\text { energy, } \\
\mathrm{kcal} / \mathrm{mol}\end{array}$ \\
\hline 2 & (V) & $\mathrm{H}$ & 75.0 & 85.0 & 72.0 & -8.6 \\
\hline 3 & (Va) & $\mathrm{p}-\mathrm{OCH}_{3}$ & 81.2 & 82.5 & 78.2 & -9.5 \\
\hline 4 & (Vb) & $\mathrm{p}-\mathrm{Cl}^{3}$ & 77.0 & 78.0 & 79.0 & -9.6 \\
\hline 5 & (Vc) & $\mathrm{p}-\mathrm{Br}$ & 55.5 & 65.2 & 60.5 & -8.9 \\
\hline 6 & (Vd) & $\mathrm{p}-\mathrm{NO}_{2}$ & 66.5 & 76.5 & 70.5 & -8.8 \\
\hline 7 & (Ve) & $\mathrm{p}-\mathrm{CH}_{3}^{2}$ & 77.5 & 82.2 & 74.5 & -9.3 \\
\hline 8 & (Vf) & $\mathrm{p}-\mathrm{F}^{3}$ & 54.0 & 32.0 & 58.0 & -9.1 \\
\hline 9 & (Vg) & $\mathrm{p}-\mathrm{OH}$ & 66.5 & 69.5 & 69.5 & -9.2 \\
\hline 10 & (Vh) & $\mathrm{m}-\mathrm{Cl}$ & 72.5 & 82.5 & 75.5 & -8.8 \\
\hline 11 & (Vi) & $\mathrm{m}-\mathrm{Br}$ & 69.0 & 76.0 & 70.0 & -8.7 \\
\hline 12 & $(\mathrm{Vj})$ & $\mathrm{m}-\mathrm{F}$ & 61.0 & 44.0 & 64.0 & -9.6 \\
\hline 13 & (Vk) & $\mathrm{m}, \mathrm{p}-\mathrm{Cl}$ & 62.5 & 68.4 & 68.5 & -9.5 \\
\hline 14 & (VI) & $\mathrm{m}, \mathrm{p}-\mathrm{OCH}_{3}$ & 65.5 & 69.3 & 67.5 & -9.0 \\
\hline 15 & $(\mathrm{Vm})$ & $\mathrm{m}-\mathrm{NO}^{3}$ & 80.0 & 83.0 & 82.0 & -9.1 \\
\hline 16 & Cis platin & & 23.60 & 24.86 & 29.32 & - \\
\hline
\end{tabular}

Lactate dehydrogenase discharge examine was performed to test the cell membrane harm incited by Compound Vf for this, the MDAMB231 cell line was refined with $10,50,100$, and $250 \mu \mathrm{M}$ concentration of compound $\mathrm{V}_{\mathrm{f}}$ and $\mathrm{LDH}$ discharged was estimated at 24,48 , and 72 hours. Predictable with the above outcomes a portion and timesubordinate increment in LDH discharge was monitered and confirming the cytotoxic capability of Compound Vf Fig. 1 was confirmed.

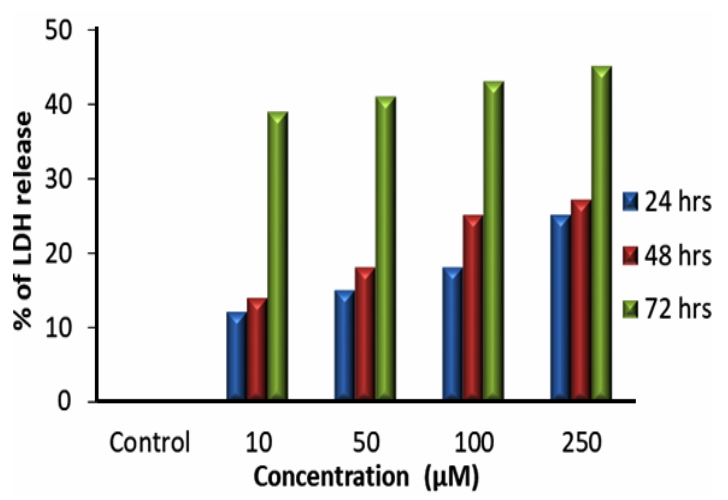

Fig. 1. LDH assay of compound Vf against MDAMB231 cell line

\section{FACS analysis}

Fluorescence-activated Cell Sorting investigation was performed to decide if compound $V_{f}$ has any impact on cell cycle movement. MDAMB231 cells were recolored with propidium iodide after $48 \mathrm{~h}$ of treatment 50 and $100 \mu \mathrm{M}$ and exposed to FACS. Histogram of the vehicle (DMSO) rewarded cells demonstrated a standard cell cycle design, which incorporates $\mathrm{G} 1$ and $\mathrm{G} 2$ isolated by the $\mathrm{S}$ stage. The subG1 step (for the most part dead cells) was not noticeable. Endless supply of compound 1, a subordinate focus change was seen in the cell cycle design Figurs 2, 3 and 4). 

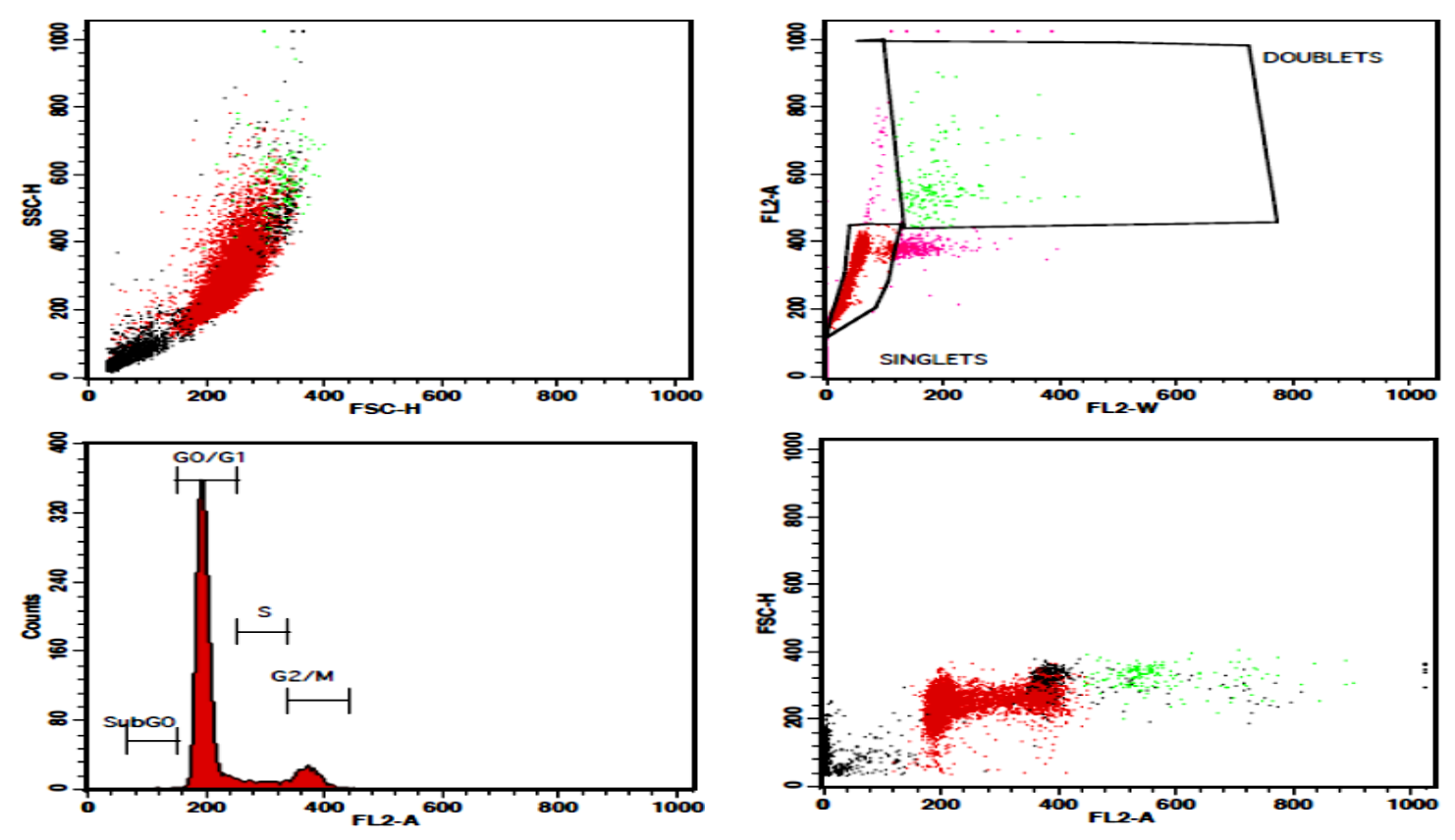

Histogram Statlstics

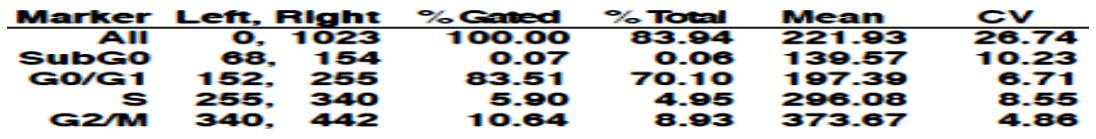

Fig. 2. Flow Cytometry Control plots of MDAMB231cells
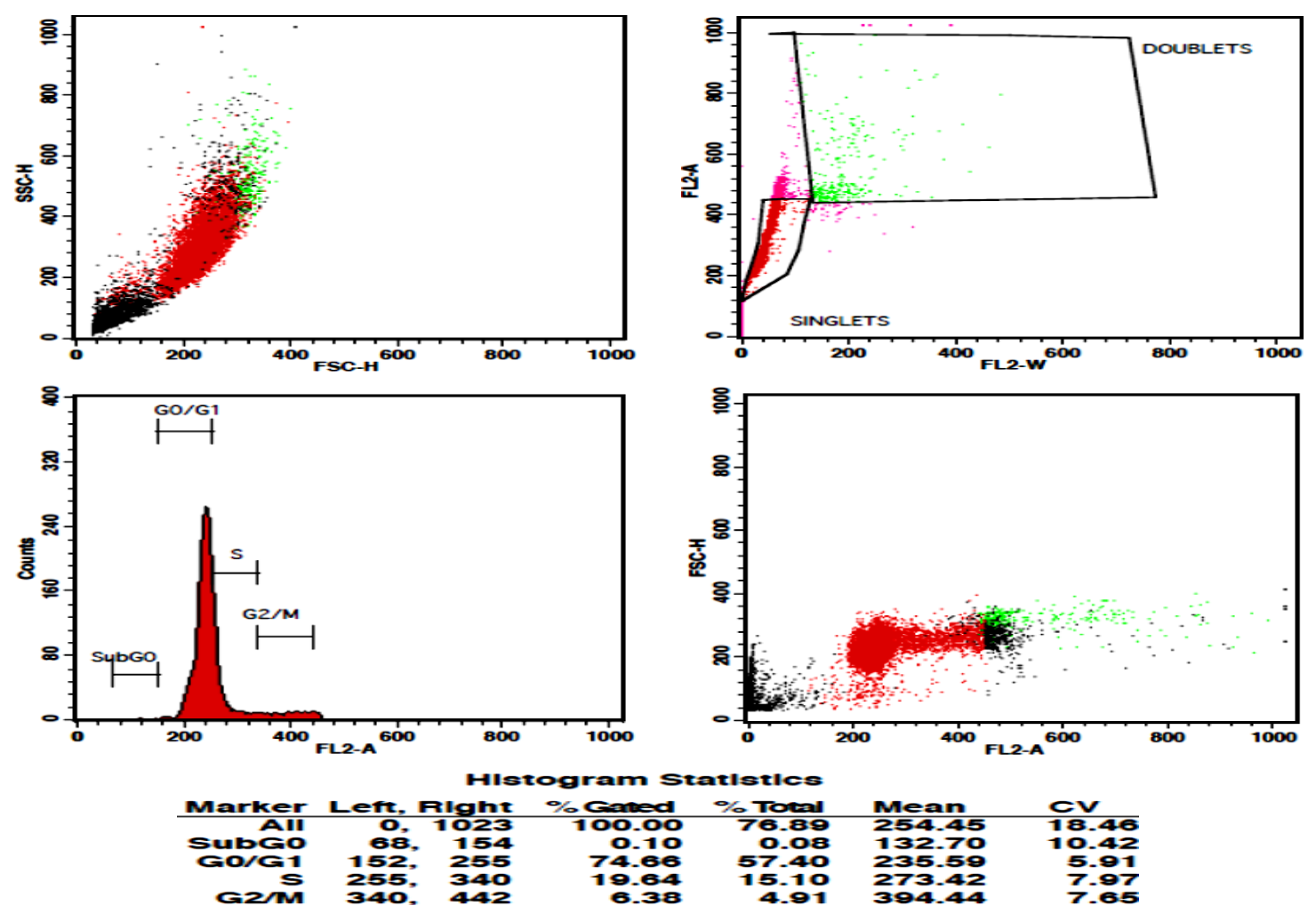

Fig. 3. Flow Cytometry plots of MDAMB231 cells treated with $50 \mu \mathrm{g} / \mathrm{mL}$ of compound Vf 

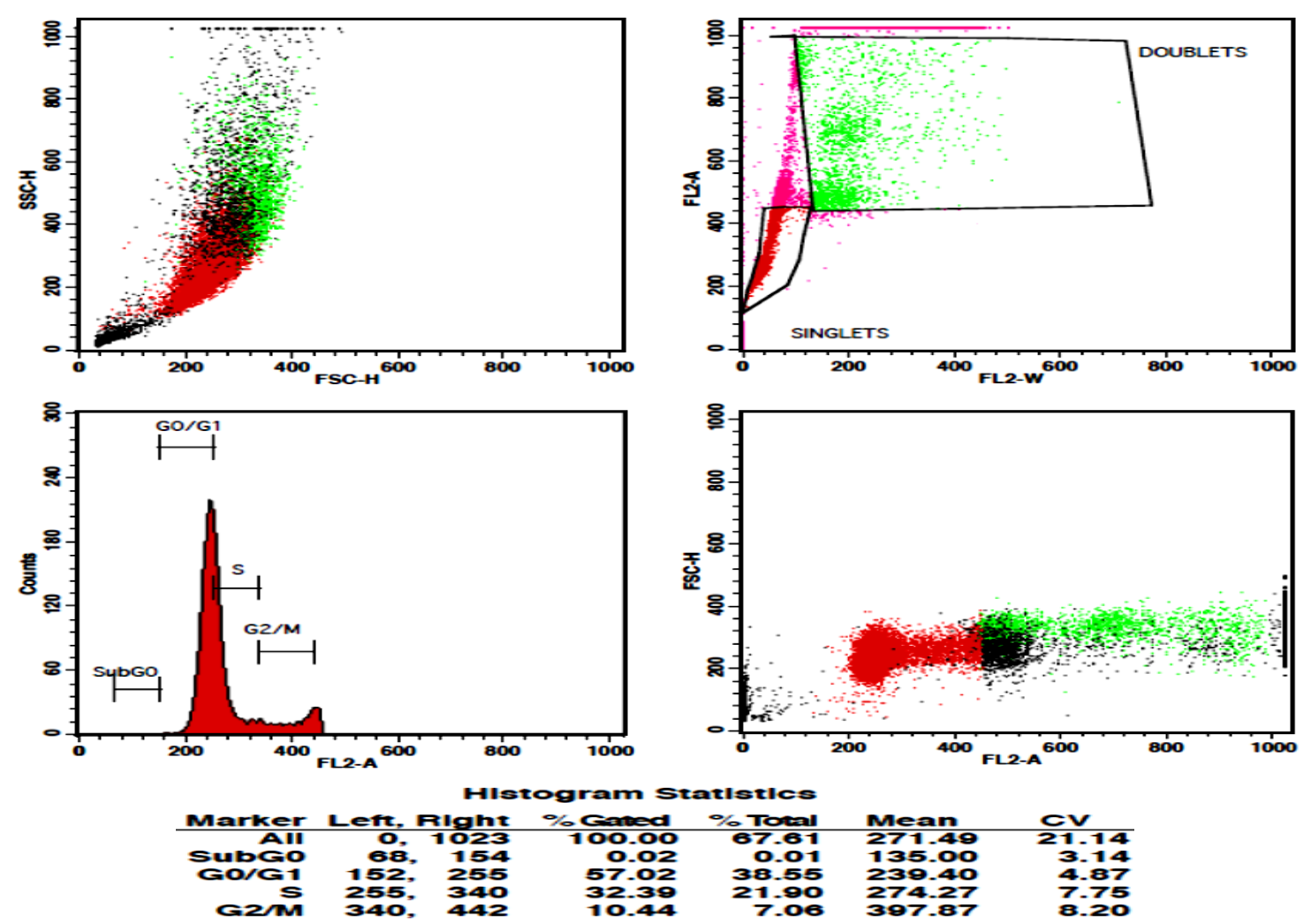

Fig. 4. Flow Cytometry plots of MDAMB231 cells treated with $100 \mu \mathrm{g} / \mathrm{mL}$ of compound Vf

Compound Vf has shown $\mathrm{S}$ arrest from $19.94 \%$ and $32.39 \%$, respectively. G2M phase arrest was found to be $6.38 \%$ and $10.44 \%$ in MDAMB231 cells. Thus, these outcomes show that compound 1 may meddle with cell division by initiating $S$ stage capture followed by apoptosis. So, more researches are required to comprehend the mechanism of cell cycle capture.

\section{Docking Score}

From the docking study, it was learned

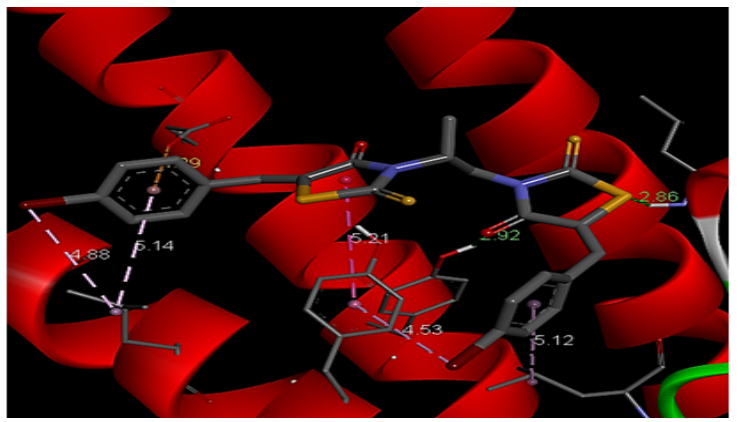

that the synthesized 5-benzylidene bis-rhodanine derivatives have a reasonable score and outstanding interactions. The compound ( $\mathrm{Vc}$ ) has an excellent binding score and Compound ( $\mathrm{Vc}$ ), sulphur and the $\mathrm{C}=\mathrm{O}$ is one of the bisrhodanine moiety form H-bonds with LEU99 and TYR32. It exhibited hydrophobic interactions with GLU100, SER98, ILE15, MET36, GLN12, TYR19, LEU94, LYS68, and GLN95.

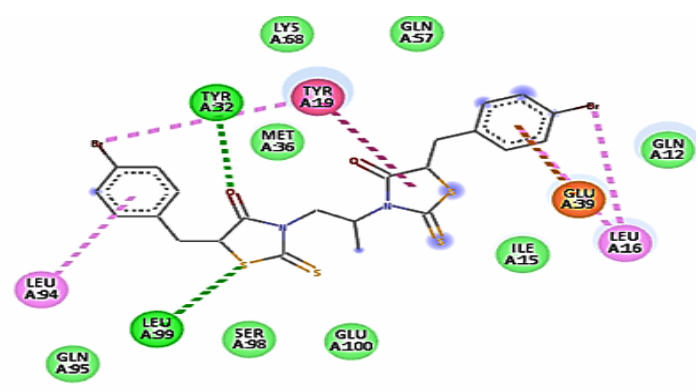

Fig. 5. 2D and 3D of compound (Vc) with 1DTO. In the 2D structure, the green color circle indicates hydrogen bond interaction

\section{CONCLUSION}

In the present work, fourteen new 5-benzylidene bis-rhodanine derivatives (V) and
(Va-m) were have been prepared, characterized by proton NMR, carbon NMR spectroscopy, elemental analysis and evaluated for their anticancer 
activities against HeLa cell lines by MTT assay, leukemic cell line K562, breast cancer cell line MDAMB231 and molecular docking studies showed better binding scores. Screening of $(\mathrm{Vc})$ and $(\mathrm{Vf})$ compounds was carried for their potential anticancer activity. The results proposed that further study of such compounds with 5-benzylidenebisrhodanine moietymay be interest.

\section{ACKNOWLEDGEMENT}

The Authors Acknowledge Central Instruments Facility, Karpagam Academy of Higher Education for providing all the equipments, instruments, chemicals and materials during this research work.

\section{Conflicts of Interest}

We declare that we have no conflict of interest.

\section{REFERENCES}

1. Whiting, E.; Raje, M. R.; Chauhan, J.; Wilder, P. T.; Eker, D. V.; Hughes, S. J.; Bowen, N. G.; Vickers, G. E. A.; Fenimor, I. C.; Fletcher, S. Bioorg. Med. Chem. Lett., 2018, 28, 523-528.

2. Mendgen, T.; Steuer, C.; Klein, C. D. J. Med. Chem., 2012, 55, 743-747.

3. Hotta, N.;Akanuma, Y.; Kawamori, R.; Matsuoka, K.; Oka, Y.; Shichiri, M. ; Toyota, T.; Nakashima, M.; Yoshimura, I.; Sakamoto, N.; Shigeta, Y. Diabetes Care., 2006, 29, 1538-1544.

4. Nagahara, K.; Anderson, J. D.; Kini, G. D.; Dalley, N. K.; Larson, S. B.; Smee, D. F; Jin, A.; Sharma, B. S.; Jolley, W. B. J. Med. Chem., 1990, 33, 407-415.

5. Nazaktabar, A.; Lashkenari, M. S.; Araghi, A.; Ghorbani, M.; Golshahi, H. Int. J. Biol. Macromol., 2017, 103, 379-384.

6. Sortino, M.; Delgado, P.; Juarez, S.; Quiroga, J.; Abonia, R.; Insuasty, B.; Nogueras, M.; Rodero, L.; Garibotto, F. M.; Enriz, R. D.; Zacchino, S. A. Bioorg. Med. Chem., 2006, 15, 484-494.

7. Kartsev, V.; Shikhaliev, K. S.; Geronikaki, A.; Medvedeva, S. M.; Ledenyova, I. V.; Krysin, M. Y.; Petrou, A.; Ciric, A.; Glamoclija, J.; Sokovic, M. Eur. J. Med. Chem., 2019, 175, 201-214.

8. Shaikh, M.S.; Kanhed, A. M.; Chandrasekaran, B.; Palkar, M. B.; Agrawal, N.; Lherbet, C.; Hampannavar, G. A.; Karpoormath, R. Bioorg. Med. Chem. Lett., 2019, 29, 2338-2344.

9. Chao, L.; Jia-Chun, L.; Ya-Ru, L.; Cheng, G.; Mei-Ling, Z.; Hong-Yan, L.; Xiao-Zhen, L.; Chang-Ji, Z.; Hu-Ri, P. Bioorg. Med. Chem. Lett., 2015, 25, 3052-3057.

10. Liu, H.; Sun, D.; Du, H.; Zheng, C.; Li, J.; Piao,
H.; Li, J.; Sun, L. Eur. J. Med. Chem., 2019, 172, 163-173.

11. Trotsko, N.; Kosikowska, U.; Paneth, A.; Wujec, M.; Malm, A. Saudi. Pharm. J., 2018, 26, 568-577.

12. Tarahomi, M.; Baharfar, R.; Mohseni, M. Clin. Microbiol. Infect., 2019, 4, 1-5.

13. Rostam, A. B.; Peyravi, M.; Ghorbani, M. Appl. Surf. Sci., 2018, 427, 17-28.

14. Kratky, M.; Vinsova, J.; ikova, J. I. S. Bioorg. Med. Chem., 2017, 25, 1839-1845.

15. Bhatt, H. B.; Sharma, S. Arab. J. Chem., 2013, 10, 1590-1596.

16. Abdel Hafez, N. A.; Elsayed, M. A.; ElShahawi, M. M.; Awad, G. E. A.; Ali, K. A. J. Heterocycl. Chem., 2018, 55, 1729-1737.

17. Wacothon, K. C.; Ludovic, P.; Anoubilé, B.;YvesAlain, B.; Rémy, L. G.; Myriam, R.; Anne, C.; Jean, P. B. Med. Chem. Res., 2015, 24, 1653-1661.

18. Celestina, S. K.; Sundaram, K.; Ravi, S. Bioorg. Chem., 2020, 97, 103640.

19. Khan, N.; Gautam, G.; Gupta, A. k. J.D.D.T., 2019, 9, 161-167.

20. Andleeb, H.; Tehseen, Y.; Shah, S. J. A,; khan, I.; Iqbal, J.; Hameed, S. RSC Advances., 2016, 6(81), 77688-77700.

21. Sim, M. M.; Ng, S. B.; Buss, A. D.; Crasta, S. C.; Goh, K. L.; Lee, S. K. Bioorg. Med. Chem. Lett., 2002, 12, 697-699.

22. Talele, T.T.; Arora, P.; Kulkarni, S. S.; Patel, M. R.; Singh, S.; Chudayeu, M.; Kaushik-Basu, N. Bioorg. Med. Chem., 2010, 18, 4630-4638. 
23. Ahn, J.H.; Kim, S. J., Park, W. S., Cho, S.Y., Ha, J. D., Kim, S. S., Kang, S. K., Jeong, D. G., Jung, S. K., Lee, S. H., Kim, H. M., Park, S. K., Lee, K. H., Lee, C. W., Ryu, S. E., \& Choi, J. K. Bioorg. Med. Chem. Lett., 2006, 16, 2996-2999.

24. Ahmed I. Khodaira, A. I.; Awadb, M K.; Gessonc, J. P; Elshaierd, Y. A. M. M. Carbohydr. Res., 2020, 487, 107894.

25. Yan, M.; Zhao, J.; Sun, D.; Sun, W.; Wenting, B. Z.; Deng, W.; Zhang, D.; Wang, L. Tetrahedron. Lett., 2017, 73(24), 3355-3362.

26. Dago, C. D.; Ambeu, C. N. T.; Coulibaly, W. K.; Bekro, Y. A.; Bekro, J. A. M.; Guevel, R. L.; Corlu, A.; Pierre Bazureau, J. Chem. Heterocycl. Compd., 2017, 53(3), 341-349.

27. Moorthy B. T.; Ravi S.; Srivastava M.; Chiruvella K. K.; Hemlal H.; Joy O.; Raghavan
S. C. Bioorganic \& Medicinal Chemistry Letters., 2010, 20, 6297-6301.

28. Ravi, S.; Chiruvella, K. K.; Rajesh, K.; Prabhu, V.; Raghavan, S. C. Eur. J. Med. Chem., 2010, 45, 2748-2752.

29. Didwagh, S. S.; Piste, P. B. J. Chem. Pharm. Res., 2013, 5(5), 271-274.

30. Kamila, S.; Biehl, E. R. Tetrahedron. Lett., 2012, 53, 3998-4003.

31. Braddock, D. C.; Cailleau, T.; Cansell, G.; Hermitage, S. A.; Pouwer, R. H.; Redmond, J. M.; White, A. J. P. Tetrahedron Asymmetry., 2010, 21, 2911-2919.

32. Arafa,W.A.A.; Shaker, R.M.; Rabeh, S.A. Heterocycles., 2016, 92, 1224-1243.

33. Harshitharaj, P. K.; Kumar, R.; Ravi, S. J. Chem. Pharm. Sci., 2016, 9(4), 2478-2482. 